\title{
FancD2 Nuclear Foci Present
}

National Cancer Institute

\section{Source}

National Cancer Institute. FancD2 Nuclear Foci Present. NCI Thesaurus. Code C84329.

A laboratory test result indicating the presence of Fanconi anemia group D2 protein nuclear foci in cells, in response to DNA damage. 